
\title{
$\begin{array}{ll}\text { Research Square } & \begin{array}{l}\text { Preprints are preliminary reports that have not undergone peer review. } \\ \text { They should not be considered conclusive, used to inform clinical practice, } \\ \text { or referenced by the media as validated information. }\end{array}\end{array}$
}

\section{Cyanide as a Primordial Reductant enables a Protometabolic Reductive Glyoxylate Pathway}

\section{Ramanarayanan Krishnamurthy ( $\nabla$ rkrishna@scripps.edu )}

Scripps Research Institute https://orcid.org/0000-0001-5238-610X

\section{Mahipal Yadav}

The Scripps Research Institute https://orcid.org/0000-0003-4394-9737

\section{Sunil Pulletikurti}

Scripps Research Institute

\section{Jayasudhan Reddy Yerabolu}

The Scripps Research Institute https://orcid.org/0000-0003-1712-5136

\section{Article}

Keywords: cyanide, prebiotic chemical pathways, metalloproteins

Posted Date: June 21st, 2021

DOl: https://doi.org/10.21203/rs.3.rs-549378/v1

License: (9) This work is licensed under a Creative Commons Attribution 4.0 International License. Read Full License

Version of Record: A version of this preprint was published at Nature Chemistry on February 3rd, 2022. See the published version at https://doi.org/10.1038/s41557-021-00878-w. 


\section{Abstract}

Investigation of prebiotic chemical pathways leading to protometabolic forerunners of metabolism has been largely based on bio-inspired (iron-mediated) reductive conversion of carbon dioxide and of carboxylic acid substrates.1,2 While attractive from a parsimony point of view, this approach has been challenging with debatable outcomes.3,4 Herein, we show that cyanide reacts with citric acid cycle (TCA) intermediates and derivatives and acts as a primordial reducing agent mediating abiotic reductive transformations. The hydrolysis of the cyanide adducts followed by decarboxylation enables the efficient reductive-decarboxylative transformation of oxaloacetate to malate and fumarate to succinate while pyruvate and a-ketoglutarate are not reduced. In the presence of glyoxylate,5,6 malonate7 and malononitrile, 8 alternative pathways emerge, which after decarboxylation produce metabolic intermediates and related compounds also found in meteorites.9 These results, along with the previous demonstration of the metal-free alpha-keto analog of the reverse-TCA cycle,4,6 suggest that (a) alternative paradigms of cyanide-based protometabolic reactions bypassing the abiotic reductivecarboxylation steps can be prebiotically viable, (b) a novel reductive glyoxylate pathway can be a precursor to the r-TCA cycle and (c) the type of sophisticated carboxylation and reduction chemistries which are part of extant metabolic cycles10,11 are an evolutionary invention mediated by complex metalloproteins11.

\section{Full Text}

This preprint is available for download as a PDF.

\section{Supplementary Files}

This is a list of supplementary files associated with this preprint. Click to download.

- Supportinglnformationfinal.pdf 